\title{
Do locals benefit from being in the 'tourist capital'? Views from Livingstone, Zambia
}

Bridget Bwalya-Umar ${ }^{1,2, *}$ and Kabwe Harnadih Mubanga ${ }^{1,3}$

${ }^{1}$ University of Zambia. Geography and Environmental Studies Department. Lusaka. Zambia.

${ }^{2}$ Geography and Economic History Department. Umeå University. Umeå. Sweden

${ }^{3}$ University of Pretoria. Department of Geography, Centre for Environmental Studies, Pretoria, South Africa.

*Corresponding author: brigt2001@yahoo.co.uk

\section{Acknowledgement}

This publication is part of the first author's research work at Umeå University, thanks to a Swedish Institute Post-Doctoral Guest Researcher Scholarship.

\section{Biographical Notes}

Bridget Bwalya Umar is a faculty member of the Department of Geography and Environmental Studies, University of Zambia; visiting researcher at Umea University, Sweden. Research interests include: Natural Resource Management, Environment and Development Studies, Rural Livelihoods and Development, Political Ecology and Smallholder Agriculture

Kabwe Harnadih Mubanga is a faculty member of the Department of Geography and Environmental Studies, University of Zambia. A doctoral candidate at the University of Pretoria, South Africa. His research interests include: Natural Resource Management, Climate Change and Development, Foods Systems 


\section{Abstract}

This study used 268 household and thirteen key informant interviews to get the views of Livingstone city residents on economic, environmental and sociocultural effects of tourism on local households and the city. Results show very few economic benefits at household level with residents perceiving big tourism related businesses, the state and its officials to be the main beneficiaries. Although tourists were commended for helping vulnerable residents, they were blamed for contributing to prostitution and diseases by local residents; and were targeted for petty thefts by unemployed youths. Sociocultural effects of tourism are significant for residents but are routinely ignored or glossed over by tourism development practitioners. Tourism had resulted in a general improvement in the city environs. It is concluded that tourism development projects must target increased benefits for residents to increase benevolent attitudes from them towards tourism in their city, and to ensure a more sustainable variant of tourism is achieved in the tourist capital.

Key Words: Sustainable tourism; Victoria Falls; socioeconomic impacts; nature based tourism, world heritage site

\section{Introduction}

Tourism is an important sector for many countries the world over. It generated an estimated USD 1.4trillion in export earnings in 2013 (UNWTO, 2014a). Growth in the sector is 
especially beneficial to developing countries, whose economies are mostly traditionally dependent on agriculture. In efforts to diversify their economies, developing countries market themselves as tourist destinations offering a range of products. Nature based tourism encompasses the bulk of the tourist attractions for most of these countries although cultural tourism is also increasingly being promoted. In Africa, countries such as South Africa, Kenya, and Tanzania boast of highly developed tourism sectors. South Africa received 9188 000 international tourists and earned USD 9994 million from international tourism in 2012. Kenya and neighbouring Tanzania earned USD 935 and USD 1713 million during the same year respectively (UNWTO, 2014b). Mitchell and Ashley (2007) observed that tourism can contribute to employment and income generation. The poor in many tourist destinations have devised means to capture benefits from tourism through employment and /or providing services that the tourism sector and tourists need (Anna Spenceley and Meyer, 2012). Scheyvens (2011) asserted that tourism not only generates jobs and foreign exchange but could also bring socio-cultural change to traditional societies by demonstrating 'modern' ways of life. This view broadens the benefits derived from tourism as it does not only restrict benefits to economical but also social and cultural.

Numerous tourism studies have focused on the macroeconomic level and espoused tourism for its benefits at national and or/regional level (Archer and Fletcher, 1996; Sinclair, 1998; (Dwyer, Forsyth and Spurr, 2004). Their assumption, based on neoliberal orthodoxy is that the macro level benefits trickle down to the local level. A persistent belief is that as long as the whole country (region) gets wealthier due to tourism development, the benefits brought by this growth will eventually trickle down to the local poor through multiple channels, such as employment, public welfare and family networks (Zeng, Carter, Lacy and Bauer, 2005; Zhao and Ritchie, 2007 cited in Muganda, Sahli, and Smith, 2010). However, this is not always the case. Ashley et al. (2000) observed that investors in the tourism sector are often 
international companies and local élites, whose profits are generally repatriated abroad or to metropolitan centers. Links with the local economy are often weak, with the possible exception of employment. The focus of donor supported tourism has been on infrastructure creation, stimulation of the private sector, macroeconomic growth and foreign exchange earnings without specifically taking the needs and opportunities of the poor into account in tourism development. Spenceley and Meyer (2012) noted that tourism studies tend to be narrowly focused on economic impacts, rather than taking into account environmental, social and cultural changes.

Calls have been made to address such reductionist approaches (Carlsen, 1999) by advocates of sustainable tourism (McDonald, 2009). Sustainable tourism is defined as tourism that meets the needs of current tourists and host populations, while enhancing opportunities for the future (UNWTO, 1999 in UNEP, 2003). The concept of sustainable tourism encompasses the three pillars of sustainable development; economic, environmental and socio-cultural (Bramwell and Lane, 2011) whose amalgamation suggests that sustainable tourism should be ecologically sensitive, economically viable and socially equitable (Nicholas, Thapa, and Ko, 2009). Sustainability from an economic perspective involves maximization and optimization of benefits and minimization of costs; equitable distribution of tourism benefits in the local host community, especially amongst the most disadvantaged groups; minimization of leakages from the local economy, thereby enhancing the multiplier effect; and stimulation of local enterprises in the local community. Environmental sustainability essentially promotes the protection of the environment, which is not only necessary for the sustainability of the tourism industry, but also valuable for life support. Social sustainability primarily involves impacts on the socio-cultural fabric of the community; the host community. Socio-cultural impacts are for the most part intangible and 
tend to occur at a slower pace and in a rather subtle manner (Swarbrooke 1999 cited in Nicholas, et al. 2009: p. 394).

Most efforts to implement sustainable tourism in Sub-Saharan Africa have focused on the promotion of nature and culture based ventures. Nature based tourism is described as all forms of tourism that, " use natural resources in a wild or undeveloped form - including species, habitat, landscape, scenery and salt and fresh-water features. It is travel for the purpose of enjoying undeveloped natural areas or wildlife' (Goodwin, 1996: p. 287). Developing countries have particular advantages in attracting tourists interested in seeing and experiencing 'wild nature' as they have areas of undeveloped land often rich in landscape, habitat and wildlife (Goodwin, 1996). Visits by tourists to such sites can generate employment and income for communities as well as help in the conservation of cultural and natural assets (UNWTO, 2005 cited in Scheyvens, 2011). Scheyvens (2011) noted that development agencies and governments are pushing for poor regions and countries to develop tourism centered squarely on a combination of beautiful 'untouched' natural and cultural attractions. The OECD (2008) asserted that nature based tourism was one of the few export or service sectors in which poor countries could develop a clear comparative advantage, given that they often possess a rich natural resource base. Conversely Spenceley (2003) argued that nature based tourism does not necessarily contribute to the conservation of biodiversity, nor must it benefit host populations and is therefore, not inherently sustainable.

Most of the areas marketed as nature based tourist destinations are managed as protected areas and nature tourism is promoted in order to provide funds for protected area management (Goodwin, 1996). Protected areas are dedicated primarily to the protection and enjoyment of natural or cultural heritage, and the maintenance of biodiversity. Consumptive use of natural resources contained therein is either prohibited or minimal. Local residents derive few benefits from such protected areas. Local communities west of the Serengeti 
National Park in Tanzania have suffered losses of USD 1 million (USD 110 per household) because of damage by wildlife, but received only USD 75000 (USD 8 per household) in compensation out of the very substantial revenue generated from tourism (OECD, 2008: p. 109). Using a case study of Mombasa Resort Town in Kenya, Akama and Kieti (2007) found that local people derived minimal benefits from the tourism industry while bearing many of the costs. A lack of benefits from tourism for local residents is a challenge for sustainable tourism development as host residents are more likely to support tourism development when they derive benefits from it. In her review of residents' perspectives in tourism research, Easterling (2004) observed that host residents' support for tourism development was directly related to the degree to which they were benefiting.

Tumusiime and Sjaastad (2014) found that benefits were capable of influencing positive attitudes among the local communities around Bwindi Impenetrable National Park in Uganda. Several scholars have acknowledged that the participation of local residents is critical to the success of tourism development (Jurowski, Uysal and Williams, 1997; Cole, 2006; Roberts, 2011; Saufi, 2013). Synman (2014) found that the employment offered by high-end ecotourism in remote, rural areas of six southern African countries offered a secure and reliable source of income for households, who had few alternatives available to them.

This paper examines the benefits from tourism for the residents of Livingstone city, Zambia. Livingstone has been dubbed 'Zambia's tourist capital' and been promoted as the country's premier tourist destination. Home to the magnificent Victoria Falls, one of the seven natural wonders of the world, and a world heritage site beside the Mosi-Oa-Tunya National Park, Livingstone city has grown from a small settler town in 1905 (Arrington, 2010) to a bustling city with a population of 139509 and population density of 201 persons per $\mathrm{km}^{2}$ in 2010 (CS0, 2012). It has fairly good international travel connections and high geographic density of tourist attractions (Dixey, 2005). When the state embarked on an 
economic diversification programme away from mining, tourism was selected as one of the priority sectors and was reclassified from a social to an economic category (Government of the Republic of Zambia, 1999). Livingstone was important in this vision and was declared a tax free zone for investments in tourism enterprises (Zambia Development Agency, 2011).Tourist arrivals and tourism related developments in the city have increased. International visitors to Zambia increased from709 948 in 2009 to 914,576 in 2013.The number of employees in the hospitality industry in southern province was 22,480 , which was 26 per cent of the national figures and the highest of any province. The province earned ZMW 1 400million (USD 219.7 million) from the tourism sector in 2013 (Ministry of Tourism and Arts, 2014).These figures show increasing benefits from tourism at a macro level. However, the tourism sector has many stakeholders who include the residents of Livingstone. The benefits (and costs) from tourism for the residents are not obvious from the macro level data. As hosts, Livingstone residents are important stakeholders who are significantly affected and are able to affect tourism success in the city. Therefore, the objective of this paper was to examine residents' views on the economic, social-cultural and environmental effects of tourism in the city of Livingstone. Results show that most residents think tourism has economically benefitted the city with only a few benefits for some households while all households bear its costs through increased prices for food and services. Sociocultural effects are reported to be both negative through increased levels of prostitution, HIV/AIDS infections and crime; and positive through improved health and education facilities; intermarriages and cultural exchange. Tourism's effect on the environment is reportedly mixed with claims of accelerated environmental degradation and improved environmental management. 


\section{Methods}

\subsection{Data collection}

We used semi structured interviews, with both closed and open ended questions to collect primary data from households. The interview schedule covered demographic data (age, gender, formal education attainment, occupation, household size) : economic and social data ( household income, number of household members in formal versus informal employment); questions on economic, social-cultural, and environmental benefits and costs related to tourism at household and city level, as well questions on which stakeholders benefited most from tourism in Livingstone. Research assistants administered the interviews face to face in the languages preferred by the respondents, which were English, Silozi, ChiTonga, ChiBemba or ChiNyanja. The research assistants divided themselves into groups of three based on their language abilities. The study utilised a systematic random sampling technique. The first household to be interviewed was selected by simple random sampling, and then every third or fourth house after that was selected depending on the size of the residential area. Interview questions included asking the respondents their views on economic, social and environmental benefits and negative aspects of tourism at both household and city level; and who benefited from tourism in Livingstone. A total of 270 questionnaires were administered and 268 were used in the subsequent data analysis. The sample size was determined through a priori power analysis using the software G Power 3.2 (Erdfelder, Faul and Buchner, 1996). The sample size of 268 provided statistical power of 0.99 for detecting moderate effect size at the (two tailed) 0.05 level of significance (Erdfelder, Faul and Buchner, 1996). Primary data was also collected from thirteen key informants who included technocrats from the municipality, and the public wildlife management agency; political leaders, representative of the heritage commission, and from the local business association. The key informants were purposively

selected on the basis of their knowledge on tourism development in Livingstone. Secondary 
data was collected by reviewing government reports, books, journals and websites. Desk analyses were conducted to determine the important categories of benefits and costs related to tourism development.

\subsection{Data analysis}

Data analysis involved the use of qualitative and quantitative data analysis techniques in a complimentary manner. The quantitative data was analyzed using the statistical analysis software MINITAB 17 Statistical Software (Minitab Inc, 2014). Analyses of variances (ANOVA) were conducted at a probability level of $p \leq 0.05$ and the means were compared using pair wise comparisons. Descriptive statistics such as means, standard deviations and percentages were also employed to analyze the data. The qualitative data was analyzed using content analysis, which is a research method for the subjective interpretation of the content of text data through the systematic classification process of coding and identifying themes or patterns (Hsiu-Fang and Shannon, 2005: p. 1278). Responses from open ended survey questions were copied into and analyzed using the qualitative data analysis software QDA Miner 3.2 (Provalis Research, 2009). The responses to each question were read through several times. Categories were then created and category names assigned based on the responses from the data. The categories were exhaustive and mutually exclusive (Constas, 1992). Each response was then examined and placed in the relevant category. Frequencies for each category were then calculated.

\subsection{Overview of the study area}

Livingstone city was named after the famous Scottish missionary and explorer, Dr. David Livingstone who explored this area extensively. Due to its proximity to the Zambezi River, 
Livingstone was established as a staging post across the Zambezi River in 1905 (Livingstone Tourism Association, 2014) and was made the capital of Northern Rhodesia (preindependence name for Zambia) in 1911. As the capital, it enjoyed excellent facilities far superior to anything elsewhere in the country (Zambia Tourist Board, 2014). Although Livingstone lost its national capital status in 1935, it has been rebranded as the nation's 'tourism capital', due to its status as the home of the world renowned Victoria Falls. The Victoria Falls was declared a World Heritage Site in 1989. UNESCO (1989)(UNESCO, 1989) described it as the world's greatest sheet of falling water and significant worldwide for its exceptional geological and geomorphological features and active land formation processes with outstanding beauty attributed to the falls, that is, the spray, mist and rainbows. This transboundary property extends over 6860 hectares and comprises 3779 hectares of the Mosioa-Tunya National Park in Zambia, 2340 hectares and 741 hectares of the riverine strip of Victoria Falls and Zambezi National Parks respectively in Zimbabwe (UNESCO, 1989).

By the beginning of 2014, 157 hospitality business entities were registered and operating out of Livingstone. These businesses provided services such as bunjee jumping, boat cruises, elephant riding, game drives, lion walks, river and walking safaris, white water rafting, helicopter flights, fishing, abseiling and short term accommodation (Ministry of Tourism and Arts, 2014). Livingstone is well connected by road, water and air (Figure 1). It accounts for about $40 \%$ of Zambia's nature based tourism (Zambia Development Agency, 2013). 


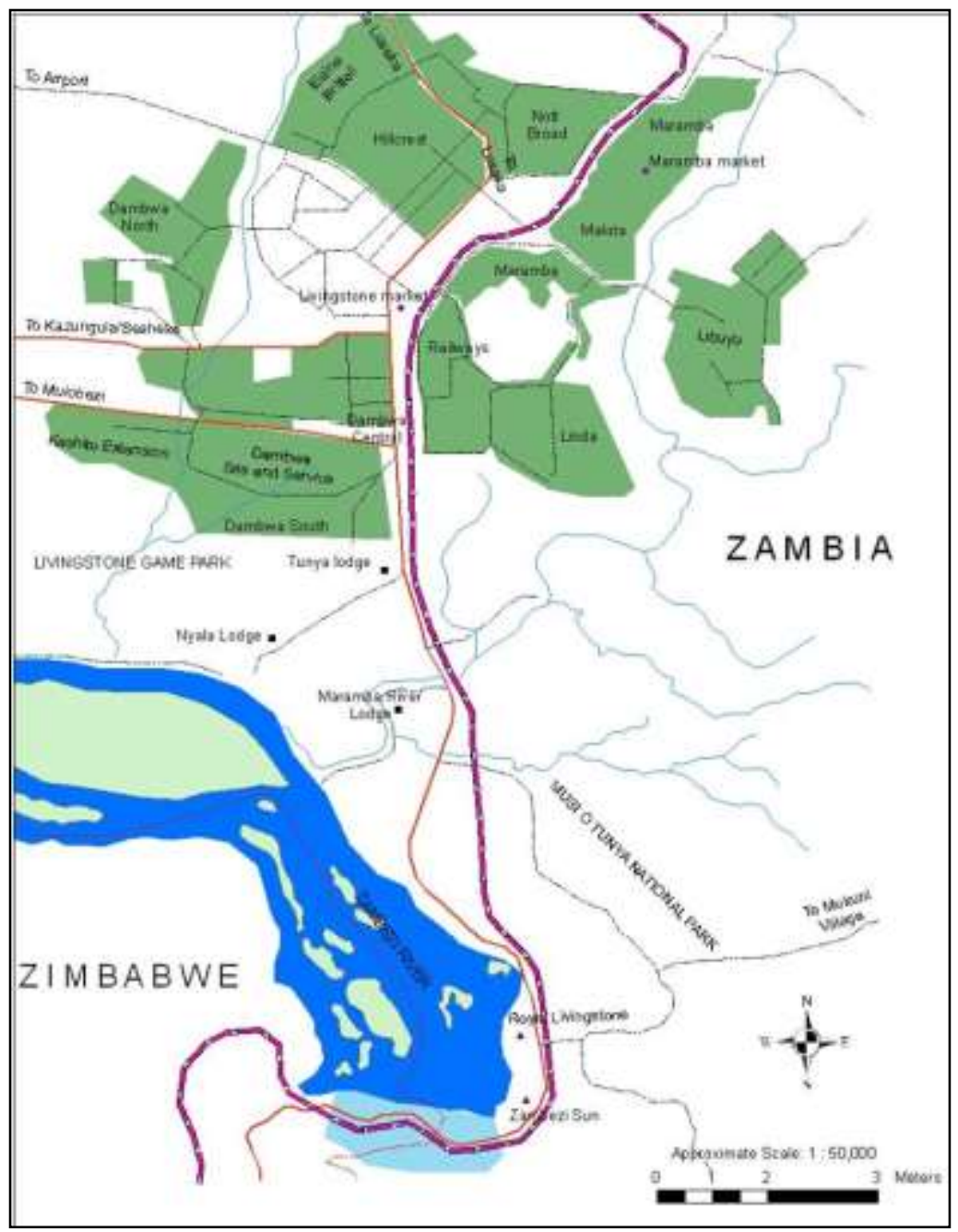

Figure 1. Livingstone city, Zambia

The Mosi-oa-Tunya National Park is the second most visited of Zambia's 19 national parks (Ministry of Tourism and Arts, 2014).

\section{Results and Discussion}

\subsection{Socio-economic characteristics of respondents}

The households sampled were categorised into three based on mean monthly incomes (low, middle and high) using their residential areas. The mean monthly household incomes for the 
Table 1 Socio-economic variables of sampled households, Livingstone

\begin{tabular}{|c|c|c|c|c|c|c|c|}
\hline $\begin{array}{l}\text { Income } \\
\text { Category }\end{array}$ & $\begin{array}{c}\text { Residential } \\
\text { Area }\end{array}$ & $\begin{array}{c}\text { Mean } \\
\text { monthly } \\
\text { household } \\
\text { income } \\
\text { (ZMW) }\end{array}$ & $\begin{array}{c}\text { Mean } \\
\text { household } \\
\text { size }\end{array}$ & $\begin{array}{l}\text { Mean years } \\
\text { of formal } \\
\text { schooling }\end{array}$ & $\begin{array}{l}\text { Mean age of } \\
\text { household } \\
\text { head (years) }\end{array}$ & $\begin{array}{l}\text { Household } \\
\text { members in } \\
\text { formal } \\
\text { employment }\end{array}$ & $\begin{array}{c}\text { Household } \\
\text { members in } \\
\text { informal } \\
\text { employment }\end{array}$ \\
\hline High & Batoka & $3191^{a}$ & $5.6^{\mathrm{a}}$ & $13.0^{\mathrm{a}}$ & $45.0^{\mathrm{a}}$ & $1.0^{\mathrm{a}}$ & $0.6^{\mathrm{a}}$ \\
\hline$(n=58)$ & Ellen Brittel & (1897) & $(2.0)$ & $(3.2)$ & (11.5) & $(0.8)$ & $(0.6)$ \\
\hline & Dambwa N & & & & & & $1.0^{\mathrm{b}}$ \\
\hline Middle & Dambwa S & $2264^{b}$ & $5.8^{\mathrm{a}}$ & $10.4^{b}$ & $44.0^{\mathrm{ab}}$ & $0.7^{\mathrm{b}}$ & $(0.8)$ \\
\hline \multirow[t]{3}{*}{$(\mathrm{n}=110)$} & Linda & (1613) & (2.6) & (3.6) & (14.6) & $(0.8)$ & \\
\hline & Maramba & & & & & & \\
\hline & Ngwenya & & & & & & $1.2^{\mathrm{b}}$ \\
\hline \multirow[t]{2}{*}{ Low } & & $1537^{\mathrm{c}}$ & $5.9^{\mathrm{a}}$ & $9.2^{\mathrm{c}}$ & $40.6^{b}$ & $0.4^{\mathrm{c}}$ & \\
\hline & Malota & (1390) & (3.3) & $(3.5)$ & (12.2) & $(0.7)$ & $(1.0)$ \\
\hline$(n=95)$ & Libuyu & & & & & & \\
\hline
\end{tabular}

Different letter superscripts along a column denote means that are statistically different at $\mathrm{p} \leq 0.05$. The figures in parenthesis are standard deviations. 
three household income categories were significantly different from each other $(\mathrm{p}<0.0001)$, hence the categorization was valid.

The mean age for household heads in the high incomes areas was higher than that for the low income areas (Table 1) but not different from that for the middle income areas. We did not find any statistically significant differences in the household sizes among the three categories of households $(\mathrm{p}=0.804)$. The high income households had the highest mean years of formal schooling for the household head, followed by the middle income households whilst the low incomes ones had the least $(\mathrm{p}<0.0001)$. The high income households also had a higher mean number of household members in formal employment, followed by middle income houses while low income households had the least number $(\mathrm{p}<0.0001)$. On the other hand, the high income households had a lower mean number of household members engaged in informal employment compared to the means for middle and low income households. These results seem to suggest that the lower income households tend to diversify their income sources by engaging in multiple low income generating activities. This is a common feature of poor households and is meant to minimise the risk associated with unstable income sources (Ellis, 1998).

\subsection{Effects of tourism on household and city economies}

The respondents were asked to state the economic benefits from tourism in Livingstone at household and city level. They reported fewer benefits for households compared to benefits accruing to the city (paired t-test. $\mathrm{t}=-16.71)$. A mean of $0.5(\mathrm{std}=0.66)$ benefits were mentioned as accruing to households yet the mean number for city was $1.48(\mathrm{std}=0.82)$. There was a perception that there are very few benefits from tourism accruing to households, with 60 per cent of the respondents reporting that they did not benefit in any way from 
tourism at household level while only 10 per cent thought the city did not benefit in any way (Figure 1).This phenomenon is similar to what was reported by Easterling (2004) when she observed that majority of residents recognized the economic potential of tourism but denied personally benefitting from it.

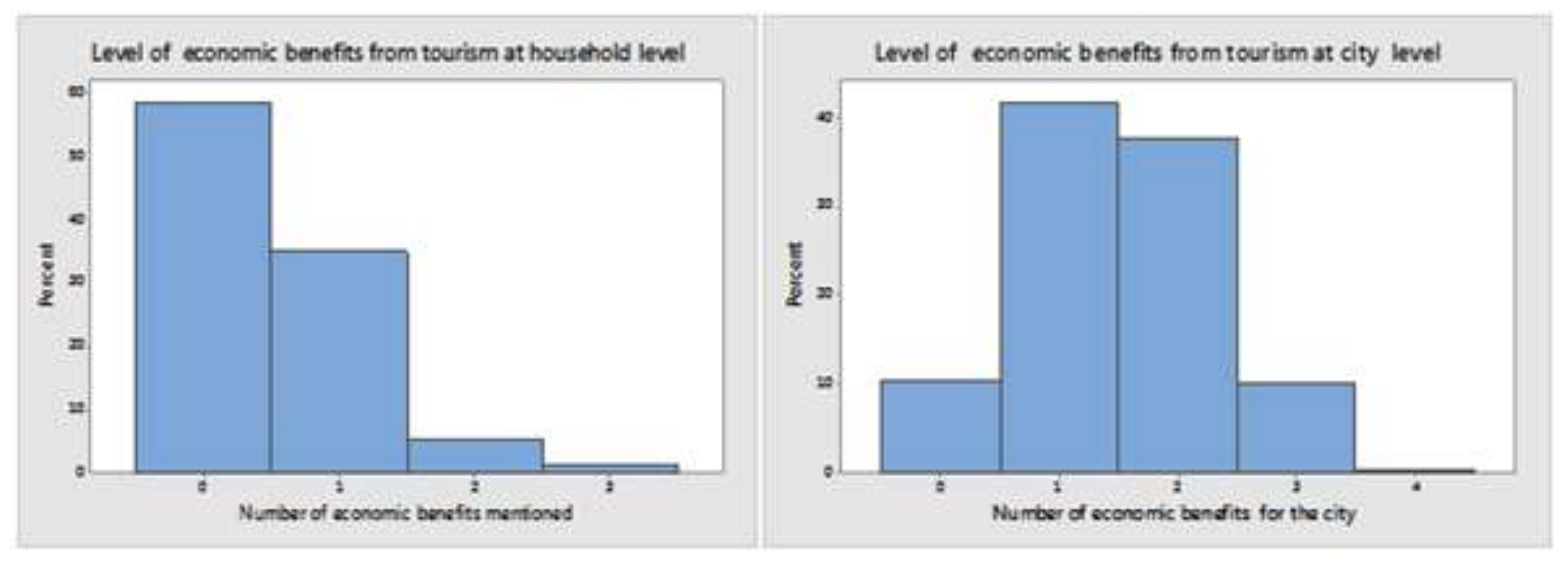

Figure 2. Levels of economic benefits for households and city

Almost a quarter $(24.2 \%)$ of the respondents reported that their households benefitted from tourism through income earned, 11.2 per cent through employment, while 1.4 per cent said it was through sharing of knowledge. The rest (3.3\%) gave answers that do not qualify as economic benefits. Tourism related household incomes were earned through activities such as trading in arts and crafts, selling food stuff to lodges and tourists, and operating taxies. Tourism related employment reported included household members working as chefs in hotels, tour guides, dancers in cultural dancing troupes, and working in lodges. A few households reported a member working as an immigration officer and one reporting a member working at the airport. With these few exceptions, most were employed in low paying jobs. As observed by Survival International (1995) while tourism promises to provide employment to the local community, the jobs are often unskilled, menial and poorly paid. Similarly, Synman (2014) reported mean monthly incomes of USD218 for households with members working for eco-tourism businesses in Zambia. We did not find any statistically significant differences in the perceptions of benefits both for households and city based on 
household income categories. This seems to suggest that level of household income did not affect respondents' perceptions of the economic benefits of tourism in Livingstone. The respondents perceived the city as economically benefitting from tourism in several ways (Table 2).

Table 2 Economic benefits of tourism in Livingstone

Economic benefit mentioned Percentage of respondents

$(n=268)$

\begin{tabular}{lc}
\hline Foreign exchange earned & 10.2 \\
Infrastructural development & 18.9 \\
Employment creation & 36.0 \\
Increased revenue for municipality & 4.2 \\
Improved markets for goods and services & 31.4 \\
Improvements in services (e.g. banking) & 9.8 \\
No idea & 4.5 \\
No benefits & 8.3 \\
\hline
\end{tabular}

The common perception was that benefits from tourism were mostly through employment and from improved markets for goods and services (from small to multi-national hotel chains). When asked to rank the actors thought to benefit most from tourism in Livingstone city, lodge owners had the highest score, while local communities had the least score (Figure 3). 


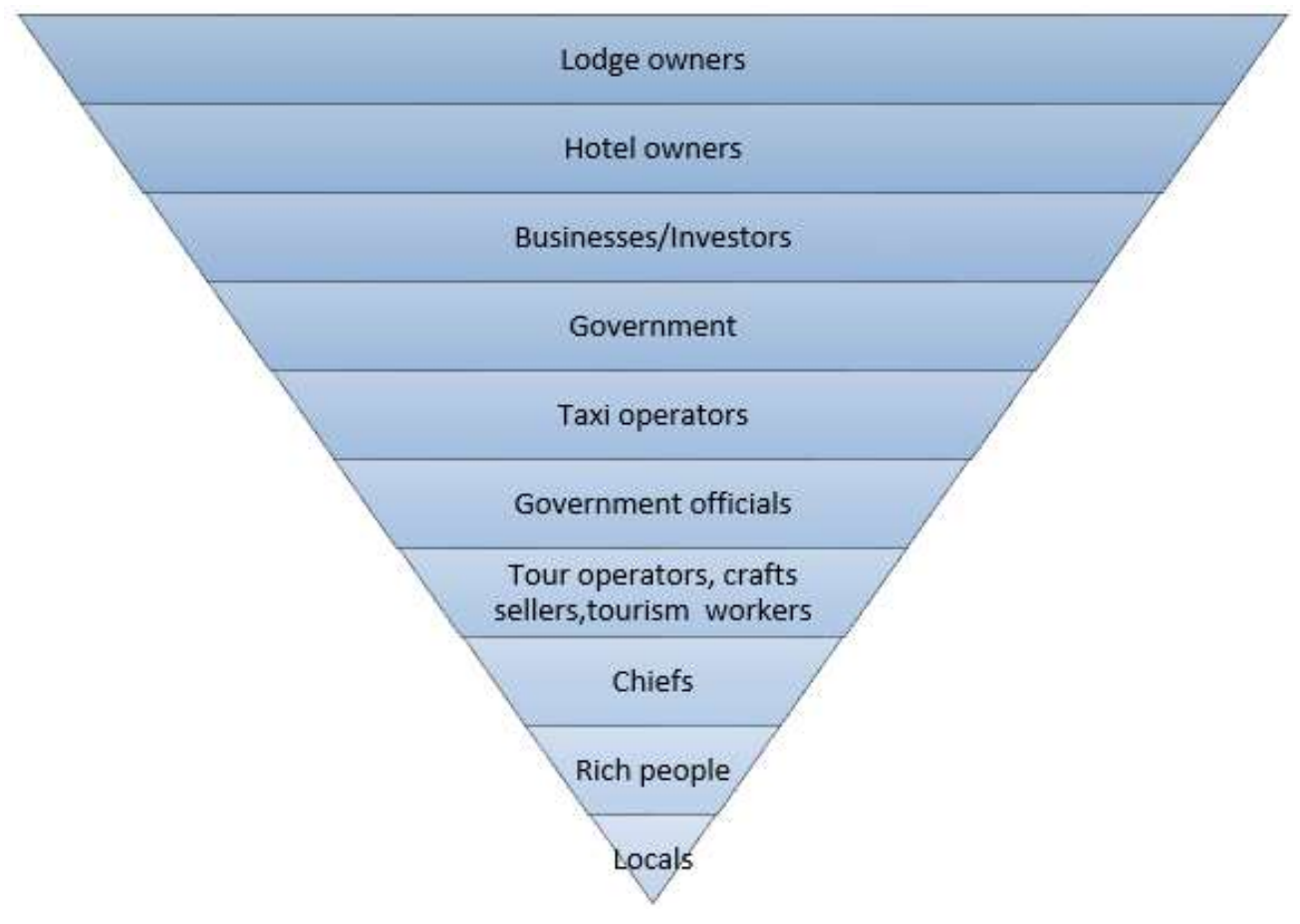

Figure 3. Rank of actors perceived to benefit from tourism in Livingstone

There was a general perception that core tourism businesses (such as hotels, lodges, tour operators, curio sellers) and related businesses (food producers, and transporters) were the main beneficiaries. The state (both central and at local level) was perceived to benefit through monies raised from charging entry fees into the national park, the museums, and the Victoria falls, Visa fees and taxes. Government officials were also perceived to benefit by virtue of their positions which allegedly provides them with opportunities for taking kickbacks. Chiefs benefit through their positions as custodians of customary land ${ }^{1}$. They are paid honoraria by investors that have built on customary land under their jurisdiction and also benefit through land transactions with investors. The tourism benefit ranking revealed that most residents did not identify themselves as beneficiaries of tourism but that such benefits accrued to individuals and business firms with the capital to engage in tourism enterprises. One of the respondents expressed his view as follows: 
'The owners of the lodges are the ones enjoying... that is why all the houses have been turned into lodges. On our side, we just feel the high rates for renting a house.' [Household Interview, $31^{\text {st }}$ November, 2012].

Another respondent put it this way:

'The people who benefit more are those who are at the top most areas, especially those who are entrusted e.g. tour guides' [Household Interview, $31^{\text {st }}$ November, 2012].

Residents that own lodges, dwelling houses or land are uniquely placed to derive individual benefits from tourism but they are in the minority. Records show 66 registered guest houses and lodges in Livingstone (Ministry of Tourism and Arts, 2014). Krippendorf (1987) referring to this 'propertied class' noted that they are a very small minority of the population, and are staunch advocates of tourism development. Respondents noted that tourism was contributing to high cost of goods and services in the city. They complained that businesses marked up their prices which were okay for tourists but too high for locals. Farmers preferred to sell their farm produce to lodges and hotels at higher prices and in bulk than selling to individuals. Some craft sellers contended that they were not benefitting from their trade as they failed to compete with large hotels that had crafts' shops on their premises. The hotel prices for crafts were said to be lower as hoteliers engaged in bulk buying and thus purchased curios from wholesalers cheaply. The craft sellers appealed to the state for preferential treatment through such activities as abolishing levies on curios as presently demanded by the local municipality and banning hotels from selling curios. However, the provincial minister, the political head of the province under which Livingstone city falls, argued that local craft sellers could not be treated preferentially when the state had embraced neo-liberal ideas and the associated free market economy which precluded such interventions [Southern Province Minister, personal communication, November $2^{\text {nd }}$ 2012]. Similar observations were made by James (2004) and Neto (2003) who noted that tourism 
development can encourage land speculation and have inflationary effects on land, food, rent, electricity, and water prices.

\subsection{Socio-cultural effects of tourism in Livingstone}

The respondents mentioned several socio-cultural benefits of tourism in Livingstone although almost a quarter thought there were none (Figure 4).

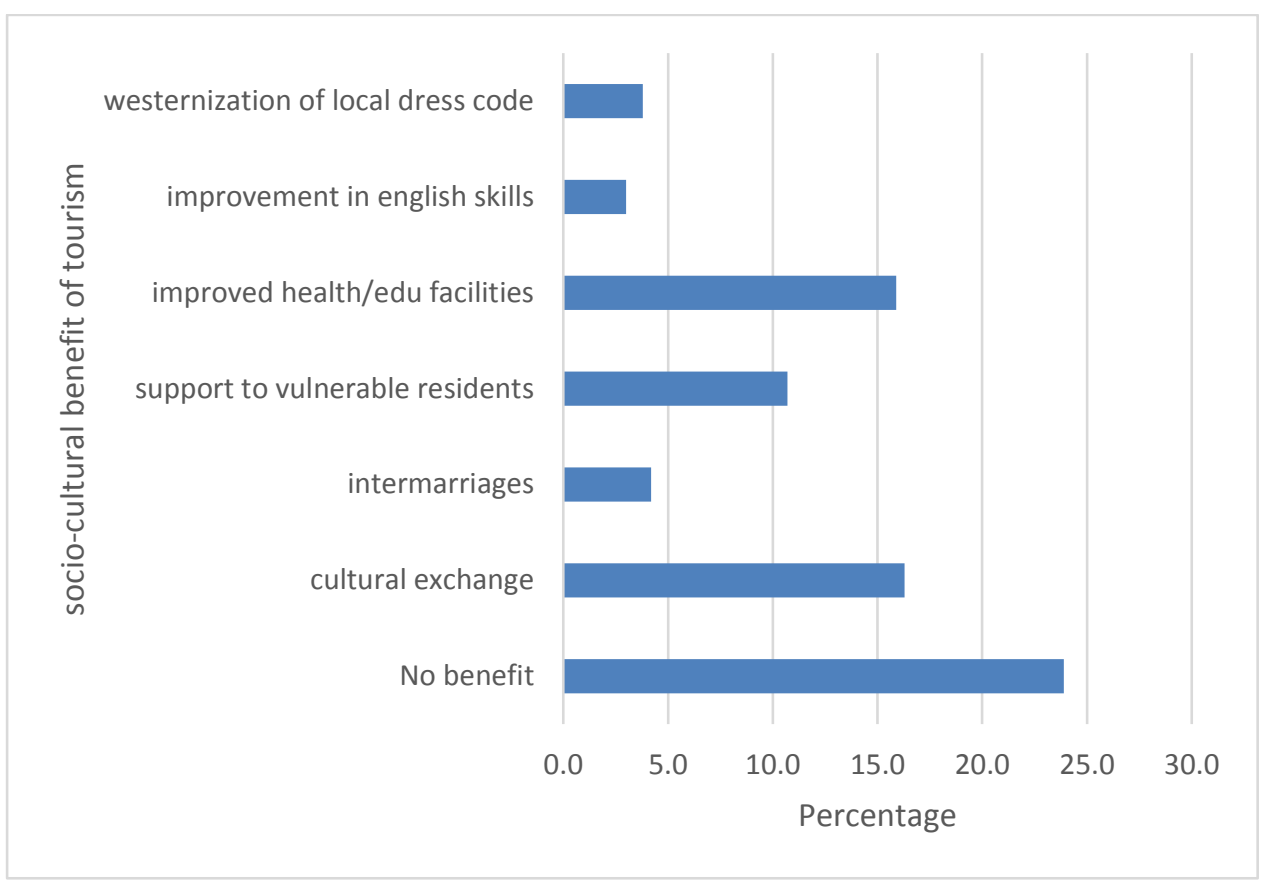

Figure 4. Socio-cultural benefits of tourism in Livingstone

It was reported that locals had adopted a more western style of dressing after seeing what the international tourists wore. This was seen as a benefit by about 4 per cent of the respondents because it helped the residents to keep up with the latest fashions. International tourists were reported to be friendly and philanthropic, attributes which benefited the host residents as most tourists made donations to orphanages, hospitals, and schools. Young residents had reportedly been motivated to improve their English speaking skills to enable 
them get jobs as tour guides. Interactions between residents and tourists result in cultural exchanges that occasionally lead to marriages. Private health providers have improved the standards of their services to attract tourists that may require them.

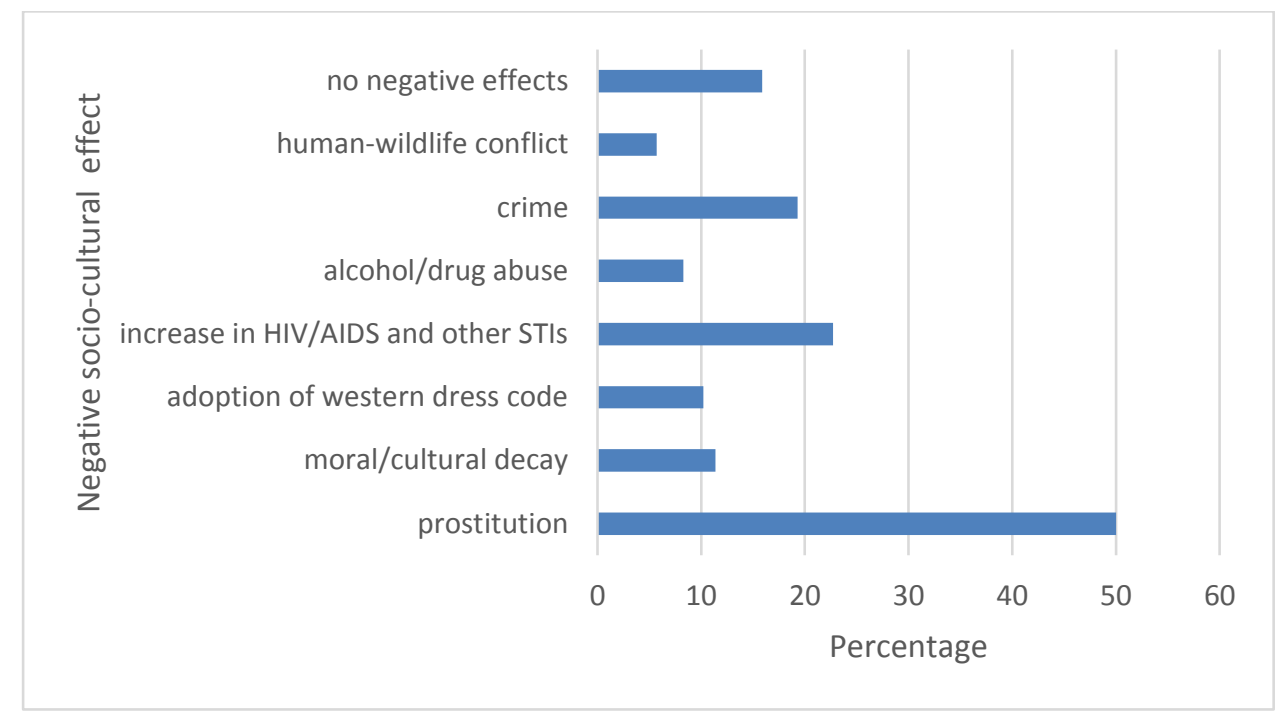

Figure 5. Negative socio-cultural effects of tourism in Livingstone

Conversely, others condemned the adoption of western dress and framed the development as an unwelcome loss of culture (Figure 4). Youths and single women were reportedly moving about 'almost naked like white tourists'. Closely linked to this was the moral/ cultural decay mentioned by 11.4 per cent of the respondents who believed that tourism had caused residents to ignore local norms in preference for western behaviours such as not respecting elders, playing of music with sexual undertones in public, and wanting to be paid for showing common courtesy e.g. helping a visitor with directions. Half of the respondents mentioned prostitution as a social vice resulting from tourism (Figure 5), caused by high unemployment, and resulting in fatherless children. One respondent put it as follows:

\footnotetext{
'Women who do not work are a lot and they go in night clubs which have been built, tourists offer them a lot of money. The result is fatherless children due to women who get pregnant from tourists.' [Household interview, November $\left.2^{\text {nd }}, 2012\right]$.
} 
The perception that tourists contribute to prostitution was widely held by residents in Livingstone. Key informants elaborated that two factors explained why this perception was ubiquitous. Firstly, prostitutes believe tourists (both domestic and foreign) have more money to spend on leisure than residents and thus target them. Concomitantly, prostitutes move into Livingstone from other places during peak tourism seasons. In the words of one key informant, "tourists are perceived as having cash to spend and to be more lucrative clients". In addition, there had been an influx of commercial sex workers as some crossed over from neighbouring Zimbabwe due to the economic decline that has characterized that country and its tourism industry in the last several years. The second reason advanced by key informants was that some tourists include 'encounters with local ladies' and 'visits to night clubs' on their lists of activities to engage in while in Livingstone. These two factors collectively contribute to the blame placed on tourists and tourism in general, for prostitution in Livingstone.

Increase in prostitution due to tourism is widely reported in literature (Easterling, 2004). Increased incidences of sexually transmitted diseases, especially HIV/AIDS were mentioned by over one fifth of the respondents as diseases that are brought by tourists. The blame was placed on international tourists who are seen as encouraging social vices due to their 'immoral behaviour' and access to money. The tourists were seen as perpetrators who paid for prostitutes because they could afford to while the locals were victims of circumstances who prostituted themselves because they had few if any alternatives. Both tourists and residents (especially the youth) were mentioned as engaging in alcohol and drug abuse (Figure 4). One respondent put it as follows:

\footnotetext{
‘.Too much drunkenness among tourists.....the bars do not close because of tourism......even young people are copying tourists and drinking alcohol and taking drugs' [Household interview, November $4^{\text {th }}{ }^{2012}$ ].
} 
Tourists were perceived as having a lot of money and able to afford lifestyles that were lavish compared to local standards. This, respondents argued, also contributed to increased crime rates. International tourists were targeted as they were perceived to be easy prey for pick pockets. Reports of human-wildlife conflicts due to elephants raiding crops or in rare instances injuring or killing humans were attributed to tourism which has necessitated the creation of Mosi-oa-Tunya National Park. The park shares boundaries with Zambezi National Park in Zimbabwe which contains a sizeable population of elephants which routinely cross back and forth between the two parks. Since Mosi-oa-Tunya National Park is much smaller than Zimbabwe National Park, the elephants frequent nearby Zambian villages in search of resources and disturb traffic on roads a few kilometres from the park. Some respondents complained that officials from the Zambia Wildlife Authority (ZAWA) valued elephants over human residents and did nothing when elephants destroyed crops and slaughtered their livestock. Key informant interviews with ZAWA officials revealed that residents' perceptions were fuelled by the current wildlife management Act (No. 12 of 1998) being silent on compensating wildlife related costs to people but explicit on punishments for people attacking wild animals [Key informant interviews, October, 2012].

\subsection{Environmental Effects of tourism in Livingstone}

The city municipality had made efforts to keep the city clean and green. The district planning officer explained that a tree planting project had been implemented with a row of exotic trees planted along the main road in the central business district [District Planning Officer, personal communication, October $\left.31^{\text {st }}, 2012\right]$. Some of the respondents had noted the development and attributed this to tourism development efforts by the local authority (Figure 6). Tree planting projects were on-going in schools as well. Almost a quarter of the 
respondents thought the city was cleaner because of tourism, while about 6 per cent thought garbage collection had improved and 2 per cent cited improved sanitation due to tourism. Some respondents (almost 35\%) did not see any benefits from tourism for the environment while 10 per cent thought tourism had directly led to the conservation of natural resources.

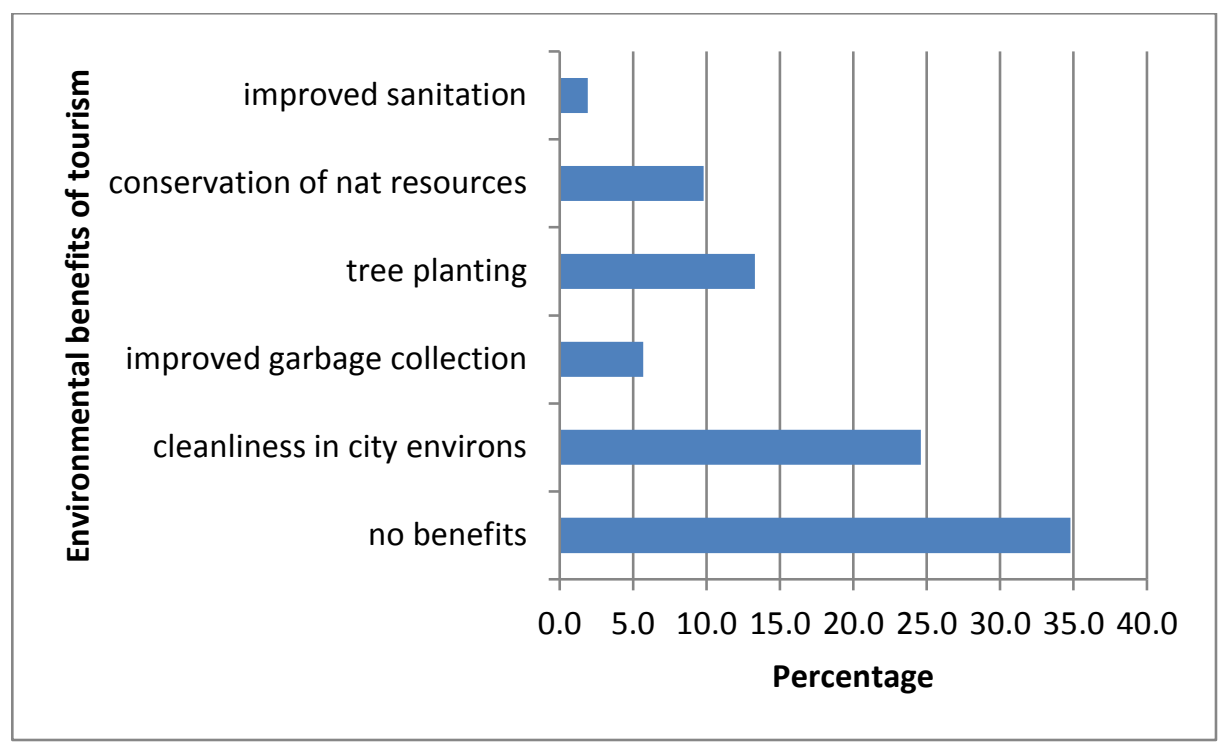

Figure 6. Environmental effects of tourism in Livingstone

Only five respondents cited negative effects of tourism on the environment, with three mentioning deforestation resulting from tourism related infrastructural development, one mentioning general environmental degradation and the other citing garbage accumulation. Deforestation resulted from infrastructural developments such as construction of hotels, lodges, housing developments, stadia, markets, and roads. One key informant narrated how the city municipality was in the habit of opening up new areas for residential plots which were purchased by speculators and left undeveloped. This land speculation has pushed up land prices and limited availability of residential housing while contribution to deforestation [Margaret Whitehead, personal communication, November $5^{\text {th }}, 2012$ ]. City council officials confirmed that the municipality was facing serious challenges with waste management. Waste disposal equipment was inadequate for the city's population (Figure 7). Efforts to sub contract waste collecting services to small locally based private enterprises had not produced 
good results as most households did not consistently pay the waste collection fees, especially in poor neighborhoods. The city's only legally designated dump site was overflowing with waste (including rotting organic refuse which was left out in the open). The lack of recycling facilities compounded the problem.

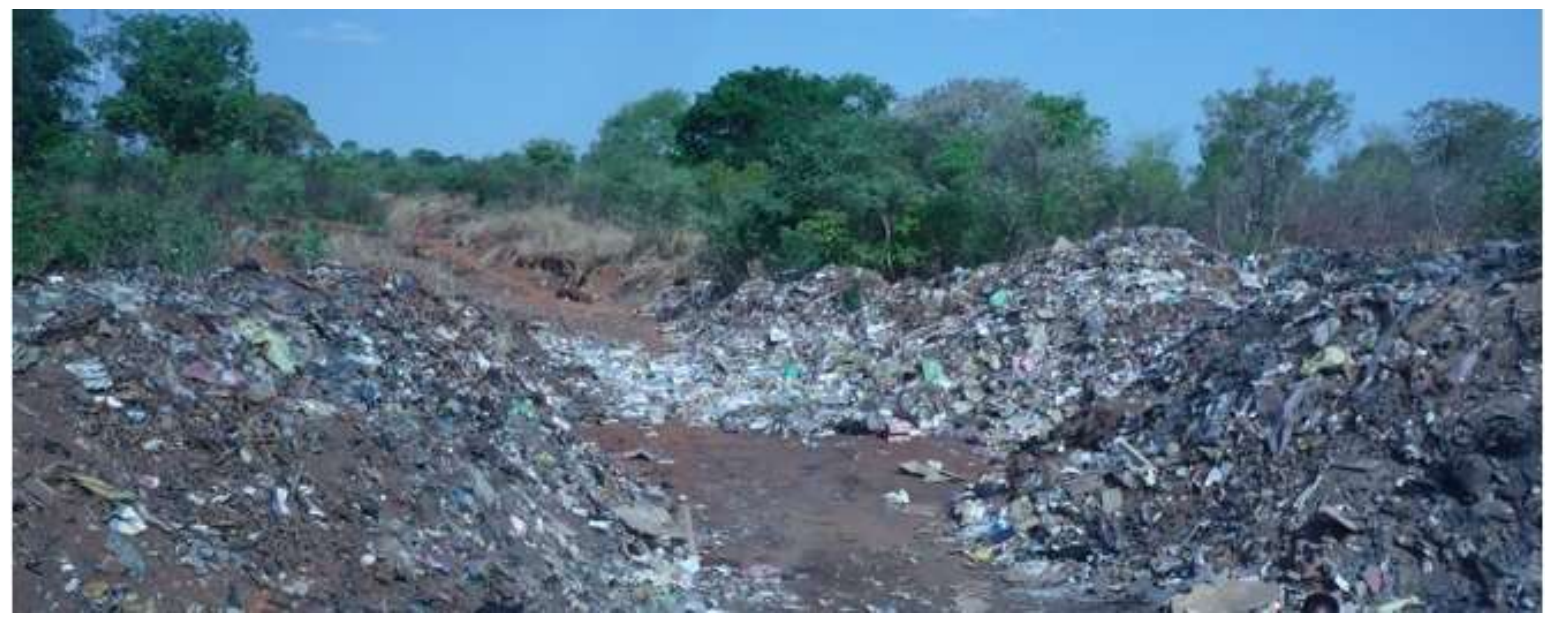

Figure 7. Part of the designated dump site for Livingstone city, November 2012.

Most residents resorted to burning their waste within their yards although this is illegal according to the local health and sanitation regulations.

\section{Conclusion}

The results of this study have shown that tourism has had both positive and negative effects on the residents of Livingstone city. Most respondents perceived tourism economic benefits as accruing to others, mainly the local elites and the city, with few if any economic benefits for their households. The higher costs of basic goods and services attributed to tourism affected poorer households more negatively as they had lower average household incomes. Low income households' tourism opportunities lay in the possibility for menial jobs and low capital business enterprises. Higher income households had opportunities for investing in various tourism enterprises, including those with high financial and human capital 
requirements. Programmes aimed at enhancing residents' participation in tourism enterprises have in the past benefitted those with financial and human capital, and excluded a large part of the residents. Such efforts, although well intended, are inimical to sustainable tourism development as they risk creating resentment among the poorer segments of the city's population and losing their support for tourism. Residents are differentiated in terms of economic class and developers of tourism development programmes need to take cognizance of such micro level differences in order to enhance the effectiveness of the programmes.

Sociocultural effects of tourism have come out strongly in this study but are routinely ignored or glossed over by tourism development practitioners. While there are programmes aimed at economic and environmental aspects of tourism being implemented by the state in the city, there are none for the sociocultural component. If not addressed, the social vices, which have a long term effect, have the potential to offset positive attributes of tourism in the

city, and engender hostile attitudes from the residents. Costs of mitigating the effects of prostitution (such as increased prevalence of HIV/AIDS and other STIs, street children), and high crime rates could become much higher than tourism benefits for the city and nation in the near future if no measures are put in place. This would jeopardize the sustainability of the tourism sector in Livingstone.

\section{Note}

1 Zambia has a dual land tenure system; customary and statutory. Customary land is controlled by the chiefs and their village heads but act with the consent of their people and govern according to local customary practices. Statutory land is held under leasehold tenure. About 94\% of land in Zambia is under customary tenure (Chizyuka, 2006; Jayne et al, 2008). 


\section{References}

Akama, J. S., \& Kieti, D. (2007). Tourism and Socio-economic Development in Developing Countries: A Case Study of Mombasa Resort in Kenya. Journal of Sustainable Tourism, 15(6), 735-748. doi: 10.2167/jost543.0

Archer, B., \& Fletcher, J. (1996). The economic impact of tourism in the Seychelles. Annals of Tourism Research, 23(1), 32-47. doi: http://dx.doi.org/10.1016/01607383(95)00041-0

Arrington, A. L. (2010). Competing for tourists at Victoria Falls: A historical consideration of the effects of government involvement. Development Southern Africa, 27(5), 773787. doi: 10.1080/0376835x.2010.522838

Bramwell, B., \& Lane, B. (2011). Critical research on the governance of tourism and sustainability. Journal of Sustainable Tourism, 19(4-5), 411-421. doi: $10.1080 / 09669582.2011 .580586$

Carlsen, J. (1999). A systems approach to island tourism destination management. Systems Research and Behavioral Science, 16(4), 321-327. doi: 10.1002/(sici)10991743(199907/08)16:4<321::aid-sres255>3.0.co;2-5

Chizyuka, R., Kamona, R., Ufwenuka, C., and Phiri, M. (2006, March). National ReportZambia: Policies and Strategies for Agrarian Reform and Rural Development to Secure and Improve Access to Natural Resources. Paper presented at the International Conference on Agrarian Reform and Rural Development Porto Alegre.

Cole, S. (2006). Information and Empowerment: The Keys to Achieving Sustainable Tourism. Journal of Sustainable Tourism, 14(6), 629-644. doi: 10.2167/jost607.0 
Constas, M. A. (1992). Qualitative Analysis as a Public Event: The Documentation of Category Development Procedures. American Educational Research Journal, 29(2), 253-266. doi: 10.3102/00028312029002253

CS0. (2012). Zambia 2010 Census of Population and Housing. Population Summary Report. Lusaka: Central Statistical Office.

Dixey, L. (2005). Inventory and Analysis of Community Based Tourism in Zambia. Lusaka: USAID.

Dwyer, L., Forsyth, P., \& Spurr, R. (2004). Evaluating tourism's economic effects: new and old approaches. Tourism Management, 25(3), 307-317. doi: http://dx.doi.org/10.1016/S0261-5177(03)00131-6

Easterling, D. S. (2004). The Residents' Perspective in Tourism Research. Journal of Travel \& Tourism Marketing, 17(4), 45-62. doi: 10.1300/J073v17n04_05

Ellis, F. (1998). Household strategies and rural livelihood diversification. The Journal of Development Studies, 35(1), 1-38. doi: 10.1080/00220389808422553

Erdfelder, E., Faul, F., \& Buchner, A. (1996). GPOWER: A general power analysis program. Behavior Research Methods, Instruments, \& Computers, 28(1), 1-11. doi: $10.3758 / \mathrm{bf} 03203630$

Goodwin, H. (1996). In pursuit of ecotourism. Biodiversity \& Conservation, 5(3), 277-291. doi: 10.1007/bf00051774

Government of the Republic of Zambia. (1999). Tourism Policy for Zambia. Lusaka: Government Printer.

Hsieh, H.-F., \& Shannon, S. E. (2005). Three Approaches to Qualitative Content Analysis. Qualitative Health Research, 15(9), 1277-1288. doi: 10.1177/1049732305276687 James, G. (2004). Riding the wave: Working within a globalised tourism economy. In Focus, $52,12-13$. 
Jayne, T. S., Zulu, B., Kajoba, G., and Weber, M. (2008). Access to land and poverty reduction in rural zambia: Connecting the policy issues. (Working Paper No. 34). Lusaka: Food Security Research Project.

Jayne, T. S., Zulu, B., Kajoba, G., and Weber, M.T. (2008). Access to land and poverty reduction in rural zambia: Connecting the policy issues. (Working Paper No. 34) Lusaka, Zambia: Food Security Research Project.

Jurowski, C., Uysal, M., \& Williams, D. R. (1997). A Theoretical Analysis of Host Community Resident Reactions to Tourism. Journal of Travel Research, 36(2), 3-11. doi: $10.1177 / 004728759703600202$

Krippendorf, J. (1987). The Holidaymakers:Understanding the impact of leisure and travel. London: Heineman.

Livingstone Tourism Association. (2014). Explore Livingstone. Retried from http://www.livingstonetourism.com

McDonald, J. R. (2009). Complexity science: an alternative world view for understanding sustainable tourism development. Journal of Sustainable Tourism, 17(4), 455-471. doi: 10.1080/09669580802495709

Ministry of Tourism and Arts. (2014). 2013 Tourism Statistical Digest. Lusaka: Ministry of Tourism and Arts.

Minitab Inc. (2014). Minitab 17 Statistical Software. State College: Minitab Inc.

Mitchell, J., and Ashley, C. (2007). Pathways to Prosperity-How can tourism reduce poverty: A review of pathways, evidence and methods. London: Overseas Development Institute.

Muganda, M., Sahli, M., \& A Smith, K. (2010). Tourism's contribution to poverty alleviation: A community perspective from Tanzania. Development Southern Africa, 27(5), 629646. doi: 10.1080/0376835x.2010.522826 
Neto, F. (2003). A New Approach to Sustainable Tourism Development:Moving Beyond Environmental Protection (DESA Discussion Paper No. 29). New York: United Nations. Department of Economic and Social Affairs.

Nicholas, L. N., Thapa, B., \& Ko, Y. J. (2009). Residents' perspectives of a world heritage site: The Pitons Management Area, St. Lucia. Annals of Tourism Research, 36(3), 390-412. doi: http://dx.doi.org/10.1016/j.annals.2009.03.005

OEDC. (2008). Natural Resources and Pro-Poor Growth: The Economics and Politics . DAC Guidelines and Reference Series. Paris: The Organisation for Economic Cooperation and Development

Provalis Research. (2009). QDA Miner Version 3.2. Montreal: Provalis Research.

Roberts, S. (2011). An exploratory analysis of factors mediating community participation outcomes in tourism. Community Development, 42(3), 377-391. doi: $10.1080 / 15575330.2010 .519041$

Saufi, A., O'Brien, D., \& Wilkins, H. (2013). Inhibitors to host community participation in sustainable tourism development in developing countries. Journal of Sustainable Tourism, 22(5), 801-820. doi: 10.1080/09669582.2013.861468

Scheyvens, R. (2011). The challenge of sustainable tourism development in the Maldives: Understanding the social and political dimensions of sustainability. Asia Pacific Viewpoint, 52(2), 148-164. doi: 10.1111/j.1467-8373.2011.01447.x

Sinclair, M. T. (1998). Tourism and economic development: A survey. The Journal of Development Studies, 34(5), 1-51. doi: 10.1080/00220389808422535

Spenceley, A. (2003). Managing Sustainable Nature Based Tourism in Southern Africa: A Practical Assessment Tool. (Unpublished Doctoral Thesis), University for Greenwich London. 
Spenceley, A., \& Meyer, D. (2012). Tourism and poverty reduction: theory and practice in less economically developed countries. Journal of Sustainable Tourism, 20(3), 297317. doi: 10.1080/09669582.2012.668909

Survival International. (1995). Tourism and Tribal Peoples. Background Sheet. Londond: Survival International.

Snyman, S. (2014). The impact of ecotourism employment on rural household incomes and social welfare in six southern African countries. Tourism and Hospitality Research, 14(1-2), 37-52. doi: 10.1177/1467358414529435.

Tumusiime, D. M., \& Sjaastad, E. (2013). Conservation and Development: Justice, Inequality, and Attitudes around Bwindi Impenetrable National Park. The Journal of Development Studies, 50(2), 204-225. doi: 10.1080/00220388.2013.841886

UNEP. (2003). Tourism and Local Agenda 21. The role of local authorities in sustainable tourism. . Paris: United Nations Environment Programme.

UNESCO. (1989). Mosi-oa-Tunya/ Victoria Falls. Ref-509. Paris: UNESCO.

UNWTO. (2014a). World Tourism Barometer (Volume 12). Madrid: United Nations World Tourism Organisation.

UNWTO. (2014b). Tourism Highlights 2014 Edition. Madrid: United Nations World Tourism Organisation.

Zambia Development Agency. (2011). Tourism Sector Profile. Lusaka: Zambia Development Agency.

Zambia Development Agency. (2013). Tourism Sector Profile. Lusaka: Zambia Development Agency.

Zambia Tourist Board. (2014). Livingstone. Retrieved from http://www.zambiatourism.com/towns/livingstone/ (Accessed 10 ${ }^{\text {th }}$ december 2014). 
Zeng, B., Carter, R.W., Lacy, T., Bauer, J (2005). Effects of tourism development on the local poor people: Case study in Taibai Region, China. Journal of Services Research, $5,131-148$. 